\title{
INFLASI DI ERA GLOBAL DENGAN PENDEKATAN PHILLIPS-CURVE
}

\author{
Sri Nawatmi \\ Universitas Stikubank Semarang \\ srinawatmi@yahoo.com
}

ABSTRACT

\begin{abstract}
This study aims to analyze inflation in Indonesia by using the New Keynesian Phillips Curve. The study used Vector Autoregressive (VAR) with the type of VECM (Vector Error Correction Model). VECM is one of restrictive VAR. The first step of VAR is determining endogenous and exogeneous variables based on the theory. Estimation results indicate that the Error Correction Term (ECT) is significantly negative (-0.675167). It means that there was the existence of the error term, and the negative sign indicates that an error capable of leading to equilibrium. Based on the results obtained of VECM calculation, expected inflation had negative effect on inflation in Indonesia (-0.913099). Indonesia output gap had positive effect (62.98311) while world output gap did not affect inflation in Indonesia. It means that domestic factors more determine inflation in Indonesia than the foreign factors. Thus, Bank Indonesia as price stabilizer will be easier to create a policy to tackle inflation because domestic factors are easier to control than the foreign factors.
\end{abstract}

Key words: inflation, VAR, VECM, Phillips Curve, New Keynesian, output gap

\section{PENDAHULUAN}

Globalisasi memiliki banyak sudut pandang. Oleh karena itu, tidak ada definisi tunggal tentang globalisasi yang mampu menguraikan dengan cermat. Tetapi di bidang ekonomi, banyak pengamat sepakat, bahwa globalisasi ekonomi banyak dikaitkan dengan peningkatan integrasi ekonomi nasional maupun internasional, baik dari sisi pasar barang, jasa, tenaga kerja maupun modal (Frankel, 2006). Globalisasi ekonomi akan menghapus seluruh batasan dan hambatan terhadap arus modal, barang dan jasa. Pasar dan produksi antar negara menjadi saling tergantung karena adanya pertumbuhan perdagangan internasional, peningkatan pengaruh perusahaan multinasional dan dominasi organisasi semacam WTO (World Trade Organization). Hal tersebut tentunya akan mempengaruhi perekonomian suatu negara.

Kelompok pro globalisasi menganggap bahwa globalisasi akan meningkatkan kesejahteraan dan kemakmuran masyarakat dunia. Oleh karena itu, diperlukan adanya perdagangan bebas utuk meningkatkan kemakmuran suatu negara. Bagi pihak yang anti globalisasi, mereka tidak setuju adanya perdagangan bebas, karena perdagangan bebas akan mengikis lingkungan hidup, hak-hak buruh, kedaulatan nasional dunia ketiga dan banyak lagi penyebab lainnya.

Dengan demikian, globalisasi ekonomi banyak dikaitkan dengan peningkatan integrasi ekonomi nasional-internasional, baik dari sisi pasar barang, jasa, tenaga kerja maupun modal (Frankel, 2006). Dari pemikiran Frankel maupun para pemikir lain seperti Romer (1991), Rogoff 
(2003), serta Ihrig, Kamin, Lindner dan Marques (2007) terdapat keserupaan pandangan bahwa globalisasi mengarah pada peningkatan dampaknya pada perilaku inflasi domestik.

Dalam perkembangannya sekarang ini, banyak peneliti berpandangan bahwa globalisasi telah mengurangi peran faktor domestik dan meningkatkan peran ekonomi global dalam proses pembentukan inflasi. Bahkan secara provokatif majalah The Economist edisi 14 September 2006 menyatakan ketidakmungkinan model tradisional perekonomian tertutup digunakan untuk memprediksi inflasi. Dengan demikian telah terjadi pergeseran pemikiran yang relatif besar dari para peneliti dengan menurunkan derajat peran domestik dengan menempatkan peran ekonomi global sebagai faktor yang lebih menentukan inflasi.

Akan tetapi, perdebatan tetap terjadi, baik dalam tataran empiris maupun teoritis. Borio dan Filardo (2006) mengajukan perspektif GlobeCentric dalam menjelaskan peningkatan peran integrasi ekonomi terhadap pembentukan inflasi atau dampaknya terhadap perilaku inflasi. Di sisi lain, ada perspektif Country-Centric yang menganggap bahwa ekses permintaan sebagai penentu tingkat inflasi berada pada ruang lingkup satu negara sehingga inflasi bersifat eksklusif, pengaruh internasional semata-mata hanya ada dalam nilai tukar dan harga impor. Sedangkan Ben Bernanke, Federal Reserve Board Chairman, mengatakan bahwa walaupun globalisasi belum secara meyakinkan mampu mengubah proses penentuan inflasi dalam perekonomian, efektifitas kebijakan moneter sekarang ini membutuhkan masukan pengaruh global.

Hasil studi empiris menunjukkan adanya hubungan negatif antara keterbukaan dengan inflasi, tetapi Romer (1993) menunjukkan hubungan yang cukup bervariasi di seluruh negeri dan hasil tersebut sensitif terhadap negara yang dimasukkan ke dalam sampel. Estimasi untuk nega- ra-negara OECD nampak lebih kuat dibanding estimasi di negara-negara sedang berkembang (Farvaque, 2009).

Chen et al (2004) menganalisis manufacturing Uni Eropa tahun 1988-2000. Mereka menemukan bahwa meningkatnya keterbukaan menyebabkan penurunan harga dengan menurunkan markup dan dengan menaikkan produktifitas.

Dari sisi teoritis, perdebatan terjadi antara aliran klasik dengan Keynes. Klasik mendasarkan pada asumsi bahwa pelaku ekonomi adalah perfect foresight, perubahan ekspektasi pelaku ekonomi terealisasi secara langsung dan sempurna dalam harga, sehingga harga bersifat fleksibel. Akan tetapi, Keynes berasumsi bahwa pelaku ekonomi adalah adaptif, pelaku ekonomi melakukan forecasting berdasarkan informasi masa lalu saja sehingga tingkat harga adalah tetap.

Pengambilan keputusan yang hanya mendasarkan pada informasi sebelumnya berpotensi melakukan kesalahan sistematis (kritik Lucas). Oleh karena itu muncul New Keynesian yang selalu merevisi kesalahannya sehingga mereka tidak melakukan kesalahan terus menerus, yang pada akhirnya dalam mengambil keputusan akan benar.

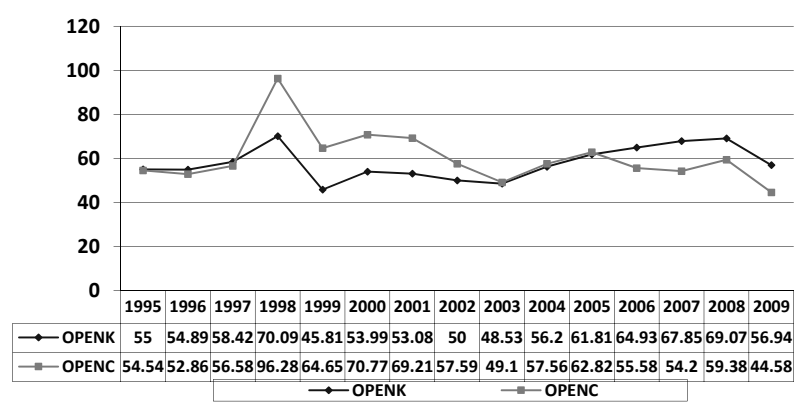

Sumber: Pennworld

\section{Gambar 1 Derajat Keterbukaan Ekonomi}

Keterbukaan ekonomi Indonesia pada grafik 1 dirumuskan dalam dua bentuk 
keterbukaan, yaitu keterbukaan berdasarkan harga konstan (Openk) dan keterbukaan berdasarkan harga berlaku (openc). Dari kedua pendekatan tentang keterbukaan tersebut terlihat bahwa hubungan ekonomi Indonesia dengan dunia internasional melalui perdagangan, baik ekspor maupun impor, merupakan sesuatu yang tidak terelakkan.

Untuk mengetahui relevansi keterbukaan ekonomi dengan tingkat harga domestik, perlu dilakukan pengukuran derajat asosiasi di antara keduanya. Melalui pengukuran sederhana, teknik korelasi Pearson, ada korelasi yang kuat diantara kedua ukuran tingkat harga ( $\mathrm{P}$ dan $\mathrm{PC}$ ) dengan ukuran keterbukaan atas dasar harga berlaku (openc), yaitu masing-masing sebesar -0,825835 dan $-0,849727$. Artinya semakin tinggi tingkat keterbukaan, semakin rendah tingkat harga domestik. Sedangkan untuk keterbukaan yang bersifat harga konstan memiliki tanda negatif namun tidak menunjukkan besaran yang berarti secara statistik (-0,203791 dan -0,159226). Adanya relevansi antara tingkat harga domestik dengan derajatketerbukaan menunjukkan masalah globalisasi tidak dapat diabaikan begitu saja dalam pembentukan harga domestik. Sedangkan perekonomian Indonesia adalah perekonomian kecil dan terbuka maka, perekonomian Indonesia tidak bisa dilepaskan dari pengaruh perekonomian global. Oleh karena itu, perlu untuk menganalisis faktor yang menentukan inflasi di Indonesia dengan menggunakan New Keynesian PhillipsCurve.

\section{REVIEW LITERATUR DAN HIPOTESIS}

Perdebatan mengenai penyebab-penyebab inflasi terus terjasi dalam ranah ekonomi makro. Perbedaan tersebut terjadi terutama dikarenakan adanya pandangan konvensional tentang pengukuran yang tepat terhadap inflasi dan juga dikarenakan adanya disparitas antara negara maju dengan negara berkembang.
Untuk menelaah inflasi digunakan pendekatan New Keynesian dimana pendekatan tersebut menggunakan pendekatan microfoundation of macroeconomics atau disebut sebagai The New Keynesian microfoundation of macroeconomics (Heinz-Peter Spahn, 2009). Dalam ekonomi, terminologi microfoundation mengacu pada analisis microeconomics dari perilaku individual seperti rumah tangga atau perusahaan yang mendukung teori makroekonomi (Barro, 1993: hal. 594). Akhir-akhir ini, makroekonomi berusaha untuk mengkombinasikan model mikroekonomi dari perilaku rumah tangga dan perusahaan untuk menderivasi hubungan antar variabel-variabel makroekonomi. Robert Lucas adalah penggagas penggunaan microfoundation atas model forecasting macroeconomics tradisional. Lucas menyatakan bahwa, hubungan antar variabel agregat yang diobservasi dalam data makroekonomi akan cenderung berubah ketika kebijakan makroekonomi berubah.

\section{New Keynesian Phillips Curve}

Perkembangan terkini dari teori moneter business cycle yang dikembangkan oleh ekonom New Keynesian melahirkan analisis kurva Phillips versi baru, New Keynesian Phillips Curve (NKPC). Oleh karena itu, teori dasar yang digunakan dalam penelitian ini adalah NKPC. Digunakannya NKPC karena faktor yang relevan menentukan inflasi adalah marginal cost. Jadi New Keynesian menunjukkan sebuah hubungan antara aktivitas riil yang diwujudkan dalam bentuk output gap dengan inflasi. Dalam konteks ini, New Keynesian mengembangkan dan mengestimasi model struktural dari Phillips Curve (Gali dan Getler, 2000).

Untuk menurunkan persamaan dari New Keynesian Phillips Curve, maka diasumsikan bahawa pasar yang dihadapi adalah pasar persaingan monopolistik (monopolistic competition). Pasar persaingan monopolistik adalah bentuk organisasi pasar dimana terdapat 
banyak penjual dari sebuah produk yang terdiferensiasi, sedangkan masuk dan keluarnya perusahaan baru ke dalam industri agak mudah dalam jangka panjang. Perusahaan-perusahaan di pasar persaingan monopolistik memiliki kekuatan monopoli atas pesaing-pesaing mereka berdasar keunikan produk mereka, lokasi yang lebih baik, pelayanan yang lebih baik, produk yang lebih bervariasi dan harga yang sedikit lebih murah, tetapi kekuatan pasar mereka sangat dibatasi oleh tersedianya produk substitusi yang dekat. Tidak seperti pasar persaingan sempurna, perusahaan di pasar persaingan monopolistik bisa menentukan karakteristik produk dan jumlah beban penjualan (misal iklan) yang akan dikeluarkan, sebagaimana dia dapat menentukan harga dan kuantitas produk tersebut.

Perusahaan di pasar persaingan monopolistik memiliki market power meski kecil. Karena memiliki market power maka, perusahaan mampu untuk merubah harga atau perusahaan sebagai price maker atau price setter. Hal itu ditunjukkan dengan persamaan berikut: $\mathrm{p}_{\mathrm{t}}=\theta \mathrm{p}_{\mathrm{t}-1}+(1-\theta) \mathrm{p}_{\mathrm{t}}^{\text {or }}$

$\mathrm{P}_{\mathrm{t}}$ adalah harga umum saat ini atau pada periode $t . \mathrm{P}_{\mathrm{t}-1}$ adalah harga sebelumnya, $\theta$ adalah probabilitas untuk tidak berubah sehingga (1 $\theta$ ) adalah probabilitas perubahan. $\mathrm{p}^{\text {or }}$ (optimal reset price) adalah harga di luar keseimbangan sehingga dia memiliki probabilitas untuk berubah. Nilai $\mathrm{p}^{\text {or }}$ ditentukan oleh discount factor $(\beta)$ dari serangkaian mc (marginal cost) nominal. Calvo memformulasi sehingga optimal reset price terkait dengan mc:

$\mathrm{p}_{\mathrm{t}}^{\text {or }}=(1-\beta \theta) \Sigma(\beta \theta)^{\mathrm{k}} \stackrel{\infty}{\mathrm{E}_{\mathrm{t}=0}}\left\{\mathrm{mc}^{\mathrm{n}}{ }_{\mathrm{t}+\mathrm{k}}\right\}$

Jika harga flexibel $(\theta=0)$ maka $\mathrm{p}$ akan bergerak proporsional terhadap mc saat ini ( $\left.\mathrm{mc}_{\mathrm{t}}\right)$. Dalam kasus ini, penelitian akan relevan jika harga bersifat tidak mudah berubah atau rigid $(\theta$ $>0)$. Karena kenaikan harga tidak proporsional dan diketahui bahwa $\pi_{\mathrm{t}} \equiv \mathrm{p}_{\mathrm{t}}-\mathrm{p}_{\mathrm{t}-1,1}$ maka: $\pi_{\mathrm{t}}=\lambda \mathrm{mc}_{\mathrm{t}}+\beta \mathrm{E}_{\mathrm{t}}\left\{\pi_{\mathrm{t}+1}\right\}$

Output gap $\left(\mathrm{Y}_{\text {gap }}\right)$ adalah selisih antara output saat ini $\left(\mathrm{Y}_{\mathrm{t}}\right)$ dengan output potensial $\left(\mathrm{Y}^{*}\right)$ dan $X_{t} \equiv Y_{t}-Y^{*}$. Jika selisih antara output saat ini dengan output potensial sama dengan nol (y $\left.-y^{*}=0\right)$ maka tidak terjadi inflasi. Inflasi hanya terjadi jika output saat ini lebih tinggi dari output potensial dimana permintaan agregat melebihi penawaran agregat.. Hal itu berarti bahwa biaya akan semakin besar. Oleh karena itu diasumsikan bahwa:

$\mathrm{mc}_{\mathrm{t}}=\kappa \mathrm{X}_{\mathrm{t}}$.

dimana $\kappa$ adalah elastisitas output terhadap marginal cost.

Kombinasi hubungan antara marginal cost dan output gap dengan persamaan (3) menghasilkan sebuah hubungan seperti kurva Phillips:

$\pi_{t}=\lambda \kappa x_{t}+\beta E_{t}\left\{\pi_{t+1}\right\}$

Dengan demikian inflasi saat ini dipengaruhi oleh output gap dan "cost push".

\section{The New Keynesian Microfoundation of Macroeconomics}

New Keynesian Macroeconomics (NKM) tunduk pada dogma baru bahwa makroekonomi harus tegas menajalankan prinsip-prinsip pertama dari teori mikro. Rumah tangga diasumsikan menjalankan optimasi kalkulus yang mengaitkan waktu luang (leisure) dengan konsumsi dengan memanfaatkan pasar keuangan yang sempurna. Sisi penawaran diorganisisr sedemikian sehingga berlaku full employment.

NKM telah menggantikan model ISLM yang kuno, tetapi juga meluruskan New Classical dari monetarisme (Heinz- Peter Spahn, 2009). Para ekonom telah mencapai sebuah consensus model yang terdiri dari sebuah fungsi konsumsi yang tergantung pada pendapatan yang diharapkan dimasa yang akan datang dan tingkat bunga riil; sebuah fungsi penawaran barang yang tergantung padaa inflasi yang diharapkan di masa yang akan datang dan output gap; dan sebuah 
fungsi reaksi tingkat bunga pada bagian dari Bank Sentral yang bertujuan untuk mengeliminasi inflasi dan output gap. Kekuatan yang diakui dari NKM adalah NKM teguh dalam menjangkarkan (anchoring) pada keputusan mikro; teori yang bersaing yang memperkenalkan variabel makro tanpa penurunan langsung dari maksimisasi utility yang dikecualikan dari Econ Tribe karena menggunakan teori "ad hoc" tanpa "proper microfondations".

Kebanyakan negara maju mengalami penurunan inflasi sejak 1990. Berdasar penelitian sebelumnya, rata-rata tingkat inflasi dipengaruhi oleh beberapa faktor. Pada negara-negara yang lebih kecil ditemukan tingkat inflasi yang lebih rendah. Jika elastisitas upah relatif adalah tinggi maka inflasi cenderung tinggi dan sebaliknya. Untuk melawan inflasi diambil kebijakan moneter kontraktif dengan menurunkan money supply dan meningkatkan tingkat bunga, dan berdasarkan derajat keterbukaan, lebih terbukanya perekonomian suatu negara, lebih rendah inflasinya.

Hasil penelitian dari Romer (1993) menunjukkan hubungan yang negatif dan signifikan antara inflasi dan keterbukaan. Hasil akhir juga menunjukkan bahwa hubungan antara inflasi dan keterbukaan lebih lemah di negaranegara yang secara politis lebih stabil dan memiliki Bank Sentral yang lebih independen. Terra (1998) mengikuti Romer (1993) dengan data sampel 114 negara dari tahun 1973 hingga 1990. Terra menemukan hasil yang sama. Sampel dibagi dalam empat grup menurut indebtedness level (tingkat hutang) dan kerangka waktu dipisahkan dalam dua periode yaitu periode predebt crisis dari tahun 1970-1981 dan periode debt crisis tahun 1982-1990. Terra menunjukkan bahwa hubungan negatif hanya dapat ditemukan dalam SICs selama krisis hutang dan hal itu tidak bisa diterapkan untuk negara-negara lain dan atau selama range waktu lainnya. Terra menyimpulkan bahwa negara-negara yang overborrowed adalah yang kurang memiliki precommitment dalam kebijakan moneternya dan karenanya hubungan negatif antara inflasi dan keterbukaan lebih kuat di antara mereka.

Dalam tulisannya Rogoff (2006) menganalisis peran faktor global dari perspektif pasar barang dan aset. Rogoff berargumen bahwa meski globalisasi melemahkan kontrol individu dari Bank Sentral melalui arbitrase harga barang dan aset, dan faktor global membantu untuk mempertajam keputusan moneter, otoritas moneter domestik masih mempertahankan kontrol yang kuat atas media dan kecenderungan inflasi jangka panjang, sekalipun dalam perekonomian yang sangat terbuka.

Ball (2006) meneliti tentang efek globalisasi terhadap inflasi, studi empiris 14 negara industri dengan menggunakan data pooling. Hasilnya menunjukkan bahwa globalisasi tidak mempengaruhi inflasi. Foreign output gap tidak signifikan dalam mempengaruhi inflasi sedangkan domestic output gap signifikan. Oleh karena itu domestic output gap menjadi variabel kunci pada Phillips curve. Variabel lain yaitu harga impor hanya akan signifikan jika harga impor berubah secara tajam. Perubahan besar jangka pendek atas harga impor terutama hasil dari perubahan nilai tukar.

Ihrig, Kamin, Lindner dan Marquez (2007) mengestimasi persamaan inflasi dengan kurva Phillips standard untuk 11 negara industri dan menggunakan estimasi ini untuk menguji beberapa prediksi dari hipotesis globalisasi dan inflasi, penulis tidak mendapatkan bukti yang mendukung bahwa globalisasi mempengaruhi tingkat inflasi. Akan tetapi mereka berargumen bahwa globalisasi mungkin mepengaruhi inflasi melalui saluran lainnya yaitu net ekspor.

Borio dan Filardo (2007) menyatakan bahwa tren inflasi menjadi lebih rendah dan lebih stabil di seluruh dunia, khususnya sejak 
1990. Mereka menyatakan bahwa globalisasi berkontribusi terhadap penurunan inflasi. Dalam rangka untuk menguraikan teorinya, peneliti mengembangkan dua gaya pendekatan. Borio dan Filardo menyimpulkan bahwa faktor global telah menggantikan peran domestik dalam perekonomian (output gap). Meski globalisasi mempengaruhi proses inflasi, kebijakan moneter masih memiliki implikasi dikarenakan lag, resiko kesalahan sistematik dan efektivitas dari kebijakan moneter domestik.

\section{METODE PENELITIAN}

Model yang banyak dikembangkan untuk menjawab kritik Lucas adalah model autoregressive yang menggambarkan dinamika variabel-variabel ekonomi. Para ahli ekonomi melihat dinamika ekonomi melalui dua cara pandang yaitu (1) bahwa masa sekarang dipengaruhi oleh masa lalu, $\mathrm{y}_{\mathrm{t}}=\mathrm{p}\left(\mathrm{y}_{\mathrm{t}-1}\right)$ atau past-lag. (2) pelaku ekonomi saat ini memiliki ekspektasi tentang masa depan, $\mathrm{y}_{\mathrm{t}=} \mathrm{f}\left(\mathrm{y}_{\mathrm{t}+1}\right)$ atau future lag (Shone, 2002: hal 7).

Adanya globalisasi telah menyebabkan perbedaan cara pandang tentang faktor penentu inflasi di suatu negara. Oleh karena itu, dengan perekonomian Indonesia yang relatif terbuka, memahami tentang dinamika inflasi menjadi sesuatu yang penting.

Penelitian ini menggunakan serangkaian prosedur ekonometrika untuk melakukan estimasi dari variabel bebas terhadap variabel terikat inflasi, serta untuk mengetahui respon variabel inflasi terhadap external shock. Adapun prosedur yang akan dilakukan untuk menjawab permasalahan disertasi ini adalah:

1. Melakukan pengujian sifat stasioner data runtun waktu dengan optimal lag-nya untuk memastikan bahwa variabel yang teramati memiliki sifat stasioner.
2. Melakukan pengujian kointegrasi (cointegration) untuk menghindari terjadinya spurious regression. Di samping itu, persamaan yang terbentuk dalam pengujian kointegrasi bisa dianggap sebagai gambaran hubungan jangka panjang antar variabel bebas dan variabel terikatnya (Green, 2000:hal 790) dan mengindikasikan proses penyesuaian yang dinamis (Wang, 2009; hal. 59).

3. Mengestimasi model Vector Autoregressiv (VAR) dengan jenis Vector Error Correction (VEC). Model VAR dengan jenis VEC adalah jenis yang restriktif dengan menentukan terlebih dahulu variabel endogen dan eksogennya berdasarkan teori.

4. Mengestimasi Impulse Respon Function (IRF) dan Forecast Error Variance Decomposition (FEVD) untuk menganalisis perubahan yang terjadi sebagai akibat adanya faktor inovasi (external shock) IRF dan FEVD adalah konsekuensi logis dari model VAR.

\section{Model Penelitian}

Dalam penelitian ini digunakan model dasar New Keynesian Phillips Curve (NKPC) sebagai berikut:

$$
\pi_{\mathrm{t}}=\mathrm{c}+\beta_{0} \pi_{\mathrm{et}}+\beta_{1} \mathrm{GI}_{\mathrm{t}}+\beta_{2} \mathrm{GW}_{\mathrm{t}}+\varepsilon_{\mathrm{t}}
$$

Keterangan:

$$
\begin{array}{ll}
\pi & =\text { Inflasi (\%) } \\
\pi_{\mathrm{e}} & =\text { inflasi yang diharapkan di masa } \\
\text { datang } & (\%) \\
\mathrm{c} & =\text { Konstanta } \\
\mathrm{t} & =\text { Periode waktu } \\
\mathrm{GI} & =\text { Output gap Indonesia } \\
\mathrm{GW} & =\text { Output gap dunia } \\
\beta & =\text { Koefisien } \\
\varepsilon & =\text { Gangguan kesalahan }
\end{array}
$$

\section{Spesifikasi Variabel dan Sumber Data}

Berdasar kerangka teoritikal dasar tentang inflasi, maka kebutuhan data untuk penelitian ini adalah: 
Tabel 1

Variabel, Spesifikasi Variabel dan Sumber

\section{Data}

\begin{tabular}{|c|c|l|c|}
\hline Variabel & Notasi & \multicolumn{1}{c|}{ Definisi Operasional } & Sumber Data \\
\hline \multicolumn{5}{|c|}{$\pi$} & $\begin{array}{l}\text { Kecenderungan kenaikan } \\
\text { harga yang diukur dengan } \\
\text { menggunakan indeks harga } \\
\text { konsumen }\end{array}$ & World Bank Data \\
\hline $\begin{array}{c}\text { Output gap } \\
\text { Indonesia }\end{array}$ & GI & $\begin{array}{l}\text { Output aktual relatif } \\
\text { terhadap output potensial } \\
\text { Indonesia }\end{array}$ & World Bank Data \\
\hline $\begin{array}{c}\text { Output gap } \\
\text { dunia }\end{array}$ & GW & $\begin{array}{l}\text { Output aktual relatif } \\
\text { terhadap output potensial } \\
\text { dunia }\end{array}$ & World Bank Data \\
\hline $\begin{array}{c}\text { Harapan inflasi } \\
\text { ne }\end{array}$ & $\begin{array}{l}\text { Inflasi yang diharapkan } \\
\text { di masa yang akan datang } \\
\text { dengan menggunakan } \\
\text { Hodrick-Prescott Filter }\end{array}$ & $\begin{array}{l}\text { Data inflasi yang } \\
\text { diolah }\end{array}$ \\
\hline
\end{tabular}

\section{Uji Akar-akar Unit}

Dalam melakukan analisis dengan menggunakan data time series (runtut waktu), uji stasioneritas sangat diperlukan. Data stasioner merupakan data runtut waktu yang tidak mengandung akar-akar unit (unitroot). Sedangkan data yang tidak stasioner akan menghasilkan spurious regression (regresi lancung) yaitu hasil regresi tidak memiliki arti ekonomi (Phillip, 1986 dan Thomas, 1997:374).

Untuk uji akar-akar unit digunakan Augmented Dickey-Fuller (ADF). yang dikembangkan berdasar pendekatan DickeyFuller (DF). Jika dibandingkan dengan uji akarakar unit lainnya maka, ADF memiliki keunggulan dari sisi kesederhanaan konseptualnya. Uji ADF mendapat sorotan dari sisi akurasi pengambilan keputusannya, karena uji ADF memilki kecenderungan untuk tidak menolak hipotesis alternatif tentang sifat stasioner yang dimiliki oleh data runtut waktu (Kwiatkowski dkk, 1992; Syczewska, 1997; Hobijn, Franses dan Ooms, 1998).

\section{Uji Kointegrasi: Metode Johansen}

Uji kointegrasi digunakan untuk menguji keberadaan hubungan jangka panjang antar variabel yang diestimasi. Pemikiran tentang kointe- grasi mulai dikenalkan Granger tahun1983, yang kemudian bersama Engel memperdalam konsep kointegrasi tahun1987. Konsep tersebut diperdalam lagi oleh Johansen dan Juselius dalam perspektif vector autoregressive model.

Berdasar sudut pandang ilmu ekonomi, konsep kointegrasi banyak digunakan sebagai alat untuk menganalisis hubungan jangka panjang. Dalam memahami kointegrasi membutuhkan pemahaman yang mendalam tentang permasalah ekonomi karena kointegrasi dibangun dari studi yang bersifat matematis. Meski demikian kointegrasi Johansen lebih disarankan penggunaannya oleh Lutkepohl (2007, hal. 25) dibanding kointegrasi lainnya.

Uji kointegrasi dilakukan setelah uji akar-akar unit dan diasumsikan terintegrasi pada derajat yang sama. Kointegrasi yang digunakan merupakan kointegrasi multivariat dengan pendekatan maksimum likehood yang akan menentukan sejumlah vektpr kointegrasi dari data runtut waktu yang bersifat non stasioner (QSM, 2007: hal. 363).

Menurut Engel dan Granger (1987) dimungkinkan terjadi kointegrasi dari dua atau lebih variabel yang tidak stasioner. Artinya, jika variabel-variabel tersebut memiliki kombinasi linier maka bisa dikatakan bahwa variabel-variabel tersebut terkointegrais dan menunjukkan adanya hubungan jangka panjang.

\section{Estimasi Model Vector Autoregression (VAR)}

Model VAR digunakan untuk menjelaskan perilaku dinamis antar variabel yang diamati dan saling memiliki keterkaitan. Awalnya, konsep VAR dibangun untuk menjawab kritik Lucas mengenai kegagalan kajian struktural yang bersifat statis, sedangkan ilmu ekonomi membutuhkan kajian yang bersifat dinamis. Sim (1980) menyatakan bahwa untuk bisa menjawab persoalan ekonomi yang bersifa dinamis maka diperlukan pendekatan yang meminimalkan pendekatan teori, sehingga bagi peneliti memungkinkan untuk 
memperlakukan variabel secara sama, tidak terpisah lagi antara variabel eksogen dan endogen.

Dasar pemikiran seperti itu sekaligus juga menunjukkkan kelemahan dari konsep VAR. Dikatakan oleh Gujarati (2009: hal. 788) bahwa: (1) sifat $a$-theoritic tersebut mengakibatkan sumbangan pemikiran model struktural dalam mengidentifikasi model menjadi terabaikan, (2) Penitikberatan pada peramalan dalam model VAR tidak terlalu sesuai dengan kajian kebijakan, (3) VAR mempunyai masalah besar dalam penentuan panjang kelambanan, sehingga menimbulkan masalah disaat menentukan jumlah sampel, (4) apabila VAR mempunyai $n$ variabel maka $n$ variabel tersebut harus memilki kointegrasi pada derajat yang sama. Apabila tidak maka, perlu transformasi data yang akan menimbulkan permasalahan baru dalam pengukuran.

\section{Estimasi Vector Error Correction Model (VECM)}

VECM adalah salah satu turunan dari VAR yang memiliki ciri adanya unsur error correction pada model. Adanya unsur error correction pada model karena untuk mengukur gerakan menjauhi titik keseimbangan jangka panjang. Hal itu berarti bahwa, model VECM bisa dijadikan petunjuk untuk model jangka pendek.

Jika $Y_{t}$ terkointegrasi pada level satu, I(1), dan variabel memiliki potensi untuk terkointegrasi, maka bentuk pertama dari VAR menjadi tidak efektif (Lutkepohl, 2007: hal 11). Oleh karena itu, akan lebih bermanfaat jika menggunakan VECM yang didapat dari model dasar VAR.

\section{Pengujian Statistik}

Uji statistik yang akan dilakukan terhadap model VECM yaitu:

1. Uji otokorelasi residual LM test. Uji ini digunakan untuk pendeteksian terhadap residual yang dihipotesiskan memiliki korelasi serial. Hipotesis nol: tidak terdapat serial korelasi di bawah orde yang ditetapkan.
2. Uji Normalitas residual yaitu dengan menggunakan metode ortogonalisasi Urzua. Dekalipun normalitas tidak terlalu diperlukan untuk validitas VAR, tetapi simpangan dari asumsi normalitas mungkin mengindikasikan dimungkinkannya perbaikan dalam model (Lutkepohl, 2007: hal. 29).

3. Uji White Heteroskedastisitas. Uji ini dilakukan untuk menguji kasamaan varian. Hipotesis nol yang dibangun adalah tidak terdapat heteroskedastisitas.

\section{Estimasi Impulse Response Function (IRF) dan Forecasting Error Variance Decomposition (FEVD)}

Adanya shocks terhadap sejumlah variabel tidak hanya berpengaruh secara langsung terhadap sejumlah variabel tersebut tetapi juga menjalar ke semua variabel endogen melalui kelambanan yang bersifat dinamis dari struktur VAR. IRF (Impulse Response Function) akan menelusuri pengaruh sebuah goncangan atau shock pada suatu waktu terhadap variabel endogen. Sedangkan FEVD (Forecast Error Variance Decomposition) digunakan untuk mengidentifikasi proporsi dari pengaruh goncangan pada sebuah variabel terhadap variabel lainnya, baik saat ini maupun di masa mendatang. Jadi FEVD mempunyai kemampuan untuk memprediksi persentase peran varian setiap variabel karena adanya perubahan pada variabel lainnya.

\section{HASIL PENELITIAN DAN PEMBAHASAN}

Dalam penelitian ini digunakan metode VECM (Vector Error Correction Model). VECM adalah salah satu turunan dari VAR yang memiliki ciri adanya unsur error correction pada model. Adanya unsur error correction pada model karena untuk mengukur gerakan menjauhi titik keseimbangan jangka panjang. Hal itu berarti bahwa, model VECM bisa dijadikan petunjuk untuk model jangka pendek. 
Untuk mengolah data digunakan software Eviews. Adapun data yang akan diolah dalam penelitian ini adalah data sekunder (time-series) berupa data tahunan mulai dari tahun 1967-2013. Data tersebut diambil dari World Bank Data.

\section{Pengujian Akar-Akar Unit}

Untuk menganalisis kestasioneran data maka perlu dilakukan uji akar-akar unit. Bila data tidak stasioner maka akan menyebabkan spurious regression yaitu regresi yang menggambarkan hubungan antara dua variabel atau lebih yang nampaknya signifikan secara statistik padahal kenyataannya tidak. Dalam penelitian ini digunakan uji unit root dengan menggunakan uji ADF (Augmented Dickey-Fuller). Jika nilai ADF lebih kecil dari nilai kritis Mc Kinnon maka data tersebut stasioner atau terintegrasi pada derajat nol.

\section{Tabel 2}

\begin{tabular}{c|c|c|c|}
\multicolumn{2}{|c|}{ Rekapitulasi Hasil Uji Akar-akar Unit } \\
\cline { 2 - 4 } Variabel & \multicolumn{3}{|c|}{ Derajad nol } \\
\cline { 2 - 4 } & Constant & $\begin{array}{c}\text { Constant \&Linier } \\
\text { Trend }\end{array}$ & None \\
\hline Inf & $-5,152278^{*}$ & $-5,086769^{*}$ & $-4,540649^{*}$ \\
\hline Lgi & $-3,630111^{*}$ & $-3,537933^{*}$ & $-3,665441^{*}$ \\
\hline Lgw & $-5,360705^{*}$ & $-5,263785^{*}$ & $-5,334843^{*}$ \\
\hline
\end{tabular}

Keterangan: ${ }^{*}=$ stasioner pada $1 \% ; * *=$ stasioner pada $5 \%$

Berdasar hasil perhitungan pada tabel 4.1 tersebut nampak bahwa semua variabel baik variabel inflasi (inf), output gap Indonesia (Lgi) maupun variabel output gap dunia (Lgw) stasioner pada derajad nol.

\section{Uji Kointegrasi}

Uji Kointegrasi digunakan untuk mendapatkan hubungan jangka panjang yang stabil antara variabel-variabel yang terintegrasi pada derajat yang sama. Berdasarkan teorema Engle dan Granger, sepasang variabel dikatakan terkointegrasi jika ada beberapa kombinasi linier yang menghasilkan stationary trend $\mathrm{I}(0)$. Akan tetapi jika serangkaian variabel tersebut tidak stasioner dan terkointegrasi mungkin memilki penyimpangan dalam jangka pendek namun tetap mengarah pada posisi keseimbangan jangka panjang melalui mekanisme koreksi kesalahan (error correction mechanism).

Tabel 3

\section{Rekapitulasi Uji Kointegrasi Johansen}

\begin{tabular}{|l|c|l|}
\hline Type Kointegrasi Johansen & $\begin{array}{l}\text { H0: No } \\
\text { Cointegration } \\
\text { Estimation }\end{array}$ & $\begin{array}{l}\text { Ha: Cointegration } \\
\text { Estimation }\end{array}$ \\
\hline $\begin{array}{l}\text { Test assume no deterministic } \\
\text { trend in data: no intercept or } \\
\text { trend in CE }\end{array}$ & Reject & $\begin{array}{l}\text { Do not reject (3 } \\
\text { cointegrating equations) }\end{array}$ \\
\hline $\begin{array}{l}\text { Test assume no deterministic } \\
\text { trend in data: with intercept } \\
\text { (no trend) in CE }\end{array}$ & Reject & $\begin{array}{l}\text { Do not reject (3 } \\
\text { cointegrating equations) }\end{array}$ \\
\hline $\begin{array}{l}\text { Test allows for linier } \\
\text { deterministic trend in data: } \\
\text { no intercept or trend in CE }\end{array}$ & Reject & $\begin{array}{l}\text { Do not reject (3 } \\
\text { cointegrating equations) }\end{array}$ \\
\hline $\begin{array}{l}\text { Test allows for linier } \\
\text { deterministic trend in data: } \\
\text { intercept (no trend) in CE }\end{array}$ & Reject & $\begin{array}{l}\text { Do not reject (3 } \\
\text { cointegrating equations) }\end{array}$ \\
\hline $\begin{array}{l}\text { Test allows for quadratic } \\
\text { deterministic trend in data: } \\
\text { intercept and trend in CE }\end{array}$ & Reject & $\begin{array}{l}\text { Do not reject (3 } \\
\text { cointegrating equations) }\end{array}$ \\
\hline
\end{tabular}

Hasil uji kointegrasi Johansen dengan menggunakan lima asumsi menunjukkan adanya kointegrasi dalam sistem persamaan. Dari lima asumsi yang ada menunjukkan bahwa variabelvariabel tersebut terkointegrasi pada tiga persamaan. Berarti, ada tiga kombinasi linier yang mungkin terjadi pada kelompok variabel endogen tersebut. Akan tetapi tidak ada mekanisme untuk menentukan tentang persamaan mana yang seharusnya dijadikan keputusan tentang persamaan jangka panjang yang harus dibangun.

Penelitian ini akan menetapkan model yang dibangun semata-mata atas dasar teori, sehingga model VAR yang diterapkan adalah bentuk VAR yang terkendala yaitu VECM.

\section{Hasil Perhitungan Vector Error Correction Model (VECM)}

Tujuan utama dari penggunaan model VECM adalah mengetahui hubungan antara perubahan variabel endogen terhadap perubahan variabel eksogen dan hasil error term mengarah 
pada ekuilibrium. Unsur penting dari model VEC adalah error term yang harus signifikan dan bertanda negatif karena signifikansi tersebut berarti bahwa eksistensi error term dalam model terbukti dan tanda negatif menunjukkan error yang mampu mengarah ke keseimbangan. Seberapa cepat proses menuju ke kesimbangan tergantung dari nilai koefisien pada error correctionnya.

Hasil perhitungan VECM di dapatkan persamaan kointegrasi yang merupakan persamaan jangka panjang dari inflasi:

$\mathrm{INF}=-0,913099 \mathrm{INFE}+62,98311 \mathrm{LGI}-1,020594 \mathrm{LGW}$

$$
(-6,31849) \quad(3,61967)
$$

Dari hasil uji signifikansi dan tanda dari variabel ECT menunjukkan signifikansi yang negatif yaitu $\mathrm{ECT}=-0,675167$ (-2,77965). Hal itu berarti bahwa ada eksistensi dari error term-nya. Tanda negatif menunjukkan error yang mampu mengarah ke keseimbangan. Di samping itu, karena VEC dibangun berdasarkan metode least square yang cukup menggunakan sampel kecil maka diperlukan asumsi yang terdiri dari asumsi serial korelasi, normalitas dan heteroskedastisitas.

Berdasar persamaan di atas nampak bahwa harapan inflasi berpengaruh negatif terhadap inflasi saat ini. Hal itu berarti bahwa meningkatnya inflasi dimasa yang akan datang sebesar satu persen menyebabkan penurunan inflasi saat ini sebesar 0,913099 persen. Dengan demikian inflasi saat ini kurang peka terhadap tingkat harga yang diharapkan di masa yang akan datang.

Di sisi lain, ternyata output gap Indonesia berpengaruh positif terhadap inflasi di indonesia. Jika output gap Indonesia meningkat sebesar satu persen maka inflasi juga akan meningkat sebesar 62.98311 persen. Semakin mengecilnya gap antara output aktual dengan output potensial berarti semakin produktif. Dengan semakin produktifnya perekonomian maka barang ditawarkan akan semakin banyak sehingga tingkat harga akan menurun.
Output gap dunia ternyata hasilnya tidak signifkan dalam mempengaruhi inflasi Indonesia. Hal itu berarti inflasi Indonesia lebih banyak dipengaruhi oleh faktor domestik dari pada faktor luar negeri. Dengan demikian maka Bank Indonesia sebagai pengendali harga barang di Indonesia akan lebih mudah dalam membuat kebijakan untuk mengatasi inflasi, karena faktor domestik lebih mudah dikendalikan dibanding faktor luar negeri.

\section{Impulse Response Function (IRF)}

IRF adalah respon sebuah variabel dependen jika mendapat goncangan atau inovasi variabel independen sebesar satu standar deviasi. Goncangan inflasi sebesar sebesar satu standar deviasi pada periode pertama akan mengakibatkan peningkatan inflasi sebesar 973,73 persen, penurunan harapan inflasi sebesar 3,98 persen, penurunan output gap Indonesia sebesar 2,31 persen dan penurunan output gap luar negeri sebesar 5, 1 persen.

Pada periode kedua, goncangan inflasi sebesar satu standar deviasi pada periode kedua akan mengakibatkan peningkatan inflasi sebesar 227, 72 persen, penurunan harapan inflasi sebesar 17,52 persen, penurunan output gap domestik sebesar 2,75 persen dan peningkatan output gap luar negeri sebesar 0,37 persen.

\section{Variance Decomposition}

Variance decomposition bertujuan untuk memisahkan pengaruh masing-masing variabel inovasi secara individual terhadap respon yang diterima suatu variabel termasuk inovasi dari variabel itu sendiri. Dengan kata lain, untuk melihat prediksi kontribusi persentase varians setiap variabel terhadap perubahan suatu variabel. Pada periode satu diketahui bahwa pengaruh guncangan inflasi itu sendiri sebesar 100 persen, sedangkan goncangan harapan inflasi, output gap domestik dan output gap luar negeri tidak mempengaruhi sama sekali. Pada periode 
berikutnya, kontribusi dari variabel harapan inflasi dan output gap luar negeri terhadap pembentukan inflasi semakin meningkat dimana kontribusi dari output gap domestik lebih tinggi dari pada kontribusi output gap luar negeri pada peride ke enam dan seterusnya.

\section{KESIMPULAN DAN SARAN}

Dengan signifikannya variabel output gap Indonesia dan tidak signifikannya variabel output gap dunia artinya sekalipun perekonomian Indonesia adalah perekonomian kecil terbuka, ternyata efek luar negeri tidak berpngaruh terhadap pembentukan inflasi di Indonesia. Oleh karena itu, diharapkan kemampuan Bank Indonesia dalam mengendalikan inflasi akan lebih baik, target inflasi yang dicanangkan akan lebih mendekati realita sehingga pelaku ekonomi menjadi lebih mudah dalam melakukan aktivitas ekonominya. Dengan demikian, perekonomian Indonesia diharapkan akan menjadi lebih kondusif.

\section{DAFTAR PUSTAKA}

Aksoy Y., A. Orphanides, D. Small, V. Wieland dan David Wilcox, 2003, A Quantitative Exploration of The Opportunistic Approach to Disinflation, CEPR Discussion Papers, no. 4073, September.

Alan A. Rabin, 2004, Monetary Theory, Edward Elgar Publishung limited.

Arintoko, 2011, Pengujian Netralitas Uang dan Inflasi Jangka Pnajang Di Indonesia, Buletin Ekonomi Moneter dan Perbankan.

Ball, L.M., 2006. Has Globalization Changed Inflation?. National Bureau of Economic Research No. 12687.

Bernanke, B. S., 2007, Globalization and Monetary Policy, Remark by the Chairman of The Board of Governors of th US Federal Reserve Syatem, at the Fourth Economic Summit, Stanford
Institute for Economic Policy Research, Stanford, California, March 2.

Borio, C., and A. Filardo, 2007. Globalization and Inflation: New Cross-Country Evidence on the Global Determinants of Domestic Inflation. Bank for International Settlements BIS Working Papers No. 227.

Brian Arthur, Steven Durlauf and David Lane, 1997, Macroeconomics and Complexity: Infaltion Theory, Santa Fe Institutes Studies in The Sciences of Complexity, vol XXVII, New York: Addison-Wesley.

Brian Snowdon and Howard R. Vane, Modern Macroeconomics-Its Origin Development and Current State.

CAI Menghan, 2008, Is Globalization Operating to Reduce Inflation: Evidence from six OECD Countries, Thesis 178.899

Carlstrom, C.T. dan T. S. Fuerst, 2006, Central Bank Independence and Inflation: A Note, Federal Reserve Bank of Cleveland Working Paper N0. 06/21: 1 $-11$.

Charles Engel, Inflation and Globalization: A Modelling Perspective, BIS (Bank for International Settlements) Paper No. 70.

Chen, Imbs dan Scott (2004), Competition, Globalization and The Decline of Inflation, CEPR Discussion Paper, No. 6495, October.

Chris Peacock dan Ursel Baumann, 2008, Globalisation, Import Prices and Inflation Dynamics, Working Paper no. 359, Bank of England

Cicarelli M. Dan Mojon B., 2005, Global Inflation, Working Paper Paper Series No. 537/Oktober 2005

Clarida, Richard; Jordi Gali; dan Mark Getler, 2002, A Simple Framework for International Monetary Policy Analisis, Journal of Monetary Econonomics,49, 913-940. 
Darwanto, 2007, Kejutan Pertumbuhan Nilai Tukar Riil Terhadap Inflasi, Pertumbuhan Output, dan Pertumbuhan Neraca Transaksi Berjalan Di Indonesia, Jurnal Ekonomi Pembangunan Vol. 12 No. 1, April 2007, hal. 15-25.

Denise Cote dan Carlos de Resende, 2008, Globalization and Inflation: The Role of China,Bank of Canada Working Paper 2008-35.

Dexter, A.S., M.D. Levi, and B.R. Nault, 2005. International Trade and the Connection between Excess Demand and Inflation. Review of International Economics, Vol.13 No.4: 699-708

Enigno, Gianluca, 2004, Real Exchange Rate Persistence and Monetary Policy Rules, Journal of Monetary Economics 51:3, 473-502.

Engel, Charles, 2011, Currency Misallignment and Optimal Monetary Policy: A Reexamination, American Economic Review 101, 2796-2822.

Engel, Charles, 2012, Inflation and Globalisation: A Modelling Perspective, BIS Paper No. 70.

Etienne Farque dan Ali Shah Syed Serfaraz, 2009, Is Asia Different? New Evidence on The Globalization-Inflation Nexus.

Feyzioglu, T and L. Willard, 2006, Does Inflation in China Affect the United States and Japan? IMF Working Paper No. 06/36.

Frankel, J., 2006. What Do Economist Mean by Globalization? Implications for Inflation and Monetary Policy. www.ksghome. harvard.edu.

Gali, J. dan Gertler, M., 2000, Inflation Dynamic: A Structural Econometric Analysis, NBER Working Paper Series.

Gregory Mankiw, 2003, Macroeconomics, Worth Publisher New York.

Gujarati, D., 2003, Basic Econometrics, McGrawHill.
Heinz-Peter Spahn, 2009, The New Keynesian Microfoundation of Macroeconomics, Hohenheimer Diskussionsbeitrage, Universitat Hohenheim.

Hooper, P., M. Spencer, and C. Dobridge, 2006. Understanding US Inflation. Global Market Research (July).

International Monetary Fund, 2006, How Has Globalization Affected Inflation? World Economic Outlook Chapter III, April.

Ihrig, Kamin, Lindner dan Marquez (2007), Some Simple Test of the Globalization and Inflation Hypothesis. International Financial Discussion Papers-Board of Governors of the Federal Reserve System No.891.

Jean-Paul Fitoussi, 2007, Globalization and Inflation, Briefing paper 2007 No. 4, Committe For Economic and Monetary Affairs, European Parliament.

Joseph P. Byrne, Fatima Kaneez dan Alexandros Kontonikas, 2010, Inflation and Globalization: A Dynamic Factor Model with Stochastic Volatility.

Kamin, S. B., M. Marazzi and J. W. Schindler, 2004, Is China's Exporting Deflation? Federal Reserve Board of Governors International Finance Discussion Paper 2004/79: 1-68.

Kumar, M. S., B. Taimur, J. Decressin, C.F. MacSonacgh, dan T. Feyziogulu, 2003, Deflation: Determinants, Risks and Policy Option-Finding of an Interdepartmental Task Force, IMF Occasional Paper 221, Washington D.C.: International Monetary Fund, June.

Lane, P. R. (1997), Inflation in Open Economics, Journal of International Economics 42, pp. 447-462.

M. Maula Al Arif dan Achmad Tohari, 2006, Peranan Kebijakan Moneter Dalam Menjaga Stabilitas Perekonomian 
Indonesia Sebagai Respon Terhadap Fluktuasi Perekonomian Dunia, Buletin Ekonomi Moneter dan Perbankan

McCandless, G.T., Jr dan W.E. Weber. 1995, Some Monetary Facts, Federal Reserve Bank of Minneapolis Quaterly Review, 19 (3): 2-11.

Michael Parkin, 2008, Macoeconomics, Pearson Addison Wesley.

Mody, A., and F. Ohnsorge, 2007. Can Domestic Policies Influence Inflation? IMF Working Paper WP/07/257.

Morel, L. 2007, The Direct Effect of China on Canadian Consumer Prices: An Empirical Assessment, Bank of Canada Discussion Paper No. 10.

Ndari Surjaningsih, G.A. Diah Utari dan Budi Trisnanto, 2012, Dampak Kebijakan Fiskal Terhadap Output dan Inflasi, Buletin Ekonomi Moneter dan Perbankan, Bank Indonesia.

N. Gregory Mankiw, 2003, Teori Makroekonomi, Erlangga.

Odusanya, I.A. dan A. A. Atanda, 2010, Analysis of Inflasion and It's Determinant in Nigeria. Pakistan Journal of Social Sciences, Vo. 7 No. 2 Pg. 97-100.

Pain, N., I. Koske, and M. Sollie, 2006. Globalization and Inflation in the OECD Economies. OECD Economics Department Working Paper No. 524.

Paul A. Samuelson \& William D. Nordhaus, 2004, Ilmu Makro Ekonomi, PT. Media Global Edukasi.

Rabin, A. A., (2004), Monetary Theory, Edward Elgar Publishing Limited.

Razin, A. Dan Loungani, P. (2005), Globalization and Disinflation: The Efficiency Channel, NBER, Working Paper 11641 September.
Rogoff, K., 2003. Globalization and Global Disinflation. Federal Reserve Bank of Kansas City.

Rogoff, K., 2006. Impact of Globalization on Monetary Policy. Federal Reserve Bank of Kansas City.

Romer, D. (1993), Openness and Inflation: Theory and Evidence, Quarterly Journal of Economics, 108 (4), pp. 865-903

Romer, D. (1998), ANew Assesment Of Openness and Inflation: Reply, Quarterly Journal of Economics, CXII (2), pp. 649-652.

Rudiger Dornbusch, Stanley Fischer \& Richard Startz, 2004, Makroekonomi, PT Media Global Edukasi.

Rugman A. M., 2001, The End Of Globalization, Random House.

Rumler F, 2007, Estimate of The Economy New Keynesian Phillips Curve for Euro Area Countries, in: Open Economy Review, $18,427-451$.

Solikin, 2004, Kurva Phillips dan Perubahan Dtruktural di Indonesia: Keberadaan, Pola Pembentukan Ekspektasi, dan Linieritas, Buletin Ekonomi Moneter dan Perbankan.

Taylor, J., 2009, Globalization and Monetary Policy: Mission imposible, The International Dimension of Monetary Policy, National Bureau of Economic Research Forth Coming.

Terra, C. T. (1998), Openness and Inflation: A New Assesment, Quarterly Journal of Economics, 113 (2), pp. 641-548

Thomas, R. L. 1997, Modern Econometrics : An Introduction, Addition-Wesley.

Totonchi J., 2011, Macroeconomies Theories and Inflation, International Conference on Economics and Finance Research IPEDR vol.4 (2011), IACSIT Press, Singapore. 